\title{
Erratum to: Investigating determinants of catastrophic health spending among poorly insured elderly households in urban Nigeria
}

Olumide Adisa

The original version of this article [1] unfortunately contained a mistake. In the subsection titled "Implications for policy" part of the text was incorrect. It read "One good example is Ghana, which has now achieved $54 \%$ comprehensive health coverage of its population, and only 2 esources are shared by the family to meet the needs of elderly members $[68,69]$." The corrected text can be found below:

"One good example is Ghana, which has now achieved $54 \%$ comprehensive health coverage of its population, and only $27 \%$ of health spending is financed out-ofpocket [41]. Strengthen safety nets: In the Nigerian context, household resources are shared by the family to meet the needs of elderly members $[67,68] . "$

The original article was corrected to reflect this.

Received: 7 October 2015 Accepted: 8 October 2015

Published online: 26 October 2015

\section{Reference}

1. Adisa O. Investigating determinants of catastrophic health spending among poorly insured elderly households in urban Nigeria. Int J Equity Health. 2015;14:79. doi:10.1186/s12939-015-0188-5.

\section{Submit your next manuscript to BioMed Central} and take full advantage of:

- Convenient online submission

- Thorough peer review

- No space constraints or color figure charges

- Immediate publication on acceptance

- Inclusion in PubMed, CAS, Scopus and Google Scholar

- Research which is freely available for redistribution (c) 2015 Adisa. Open Access This article is distributed under the terms of the Creative Commons Attribution 4.0 International License (http://creativecommons.org/licenses/by/4.0/), which permits unrestricted use, distribution, and reproduction in any medium, provided you give appropriate credit to the original author(s) and the source, provide a link to the Creative Commons license, and indicate if changes were made. The Creative Commons Public Domain Dedication waiver (http:// creativecommons.org/publicdomain/zero/1.0/) applies to the data made available in this article, unless otherwise stated. 